\title{
An evaluation of the forecast of the indicator of the labour market gap
}

Citation for published version (APA):

Dupuy, A. (2009). An evaluation of the forecast of the indicator of the labour market gap. ROA. ROA Technical Reports No. 3 https://doi.org/10.26481/umarot.2009003

Document status and date:

Published: 01/01/2009

DOI:

10.26481/umarot.2009003

Document Version:

Publisher's PDF, also known as Version of record

\section{Please check the document version of this publication:}

- A submitted manuscript is the version of the article upon submission and before peer-review. There can be important differences between the submitted version and the official published version of record.

People interested in the research are advised to contact the author for the final version of the publication, or visit the DOI to the publisher's website.

- The final author version and the galley proof are versions of the publication after peer review.

- The final published version features the final layout of the paper including the volume, issue and page numbers.

Link to publication

\footnotetext{
General rights rights.

- You may freely distribute the URL identifying the publication in the public portal. please follow below link for the End User Agreement:

www.umlib.nl/taverne-license

Take down policy

If you believe that this document breaches copyright please contact us at:

repository@maastrichtuniversity.nl

providing details and we will investigate your claim.
}

Copyright and moral rights for the publications made accessible in the public portal are retained by the authors and/or other copyright owners and it is a condition of accessing publications that users recognise and abide by the legal requirements associated with these

- Users may download and print one copy of any publication from the public portal for the purpose of private study or research.

- You may not further distribute the material or use it for any profit-making activity or commercial gain

If the publication is distributed under the terms of Article $25 \mathrm{fa}$ of the Dutch Copyright Act, indicated by the "Taverne" license above, 
An evaluation of the forecast of the indicator of the labour market gap

Arnaud Dupuy

ROA-TR-2009/3

Research Centre for Education and the Labour Market

Maastricht University

P.O. Box 616, 6200 MD Maastricht, The Netherlands

$\mathrm{T}+31433883647 \mathrm{~F}+31433884914$

secretary-roa@maastrichtuniversity.nl

www.roa.nl 


\title{
An evaluation of the forecast of the indicator of the labour market
}

\author{
Arnaud Dupuy \\ ROA-TR-2009/3 \\ July 2009
}

Research Centre for Education and the Labour Market

Maastricht University

P.O. Box 616, 6200 MD Maastricht, The Netherlands

$\mathrm{T}+31433883647 \mathrm{~F}+31433884914$

secretary-roa@maastrichtuniversity.nl

www.roa.nl 


\section{Preface}

This evaluation study has been conducted within the framework of the Education and Labour Market Project (POA). The project is funded by the Ministry of Education, Culture and Science (OCW), the Institute for Employee Benefit Schemes (UWV), the UWV Werkbedrijf (formerly: Centre for Work and Income - CWI), the Ministry of Agriculture, Nature and Food Quality, the national centres of expertise on vocational education, training and the labour market represented by their association COLO, Randstad Nederland and the Council for Work and Income (RWI). The author acknowledges the members of the accompanying committee of the Education and Labour Market Project for their comments on an earlier version.

Deze evaluatiestudie heeft plaatsgevonden in het kader van het Project OnderwijsArbeidsmarkt(POA). Ditprojectwordtgefinancierd doorhet Ministerievan Onderwijs, Cultuur en Wetenschap (OCW), het Uitvoeringsinstituut Werknemersverzekeringen (UWV), het UWV Werkbedrijf (voormalig CWI), het Ministerie van Landbouw, Natuur en Voedselkwaliteit (LNV), de samenwerkende kenniscentra voor beroepsonderwijs en bedrijfsleven COLO, Randstad Nederland en de Raad voor Werk en Inkomen (RWI). De auteur bedankt de leden van de begeleidingscommissie van het Project Onderwijs-Arbeidsmarkt voor het commentaar op een eerdere versie. 


\title{
An evaluation of the forecast of the indicator of the labour market gap
}

\author{
Arnaud Dupuy
}

July 6, 2009

\section{Contents}

1 Introduction $\quad 3$

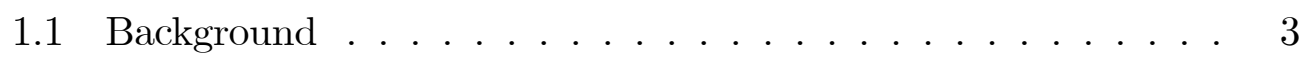

1.2 Motivation for the evaluation ............. . . . . . . . 4

1.3 Goal and structure of the forecast . . . . . . . . . . . 5

1.4 Structure of the report . . . . . . . . . . . . . . . 11

2 Confrontation of demand and supply 13

2.1 Introduction . . . . . . . . . . . . . . . . . 13

2.2 Labour market indicator . . . . . . . . . . . . . . . . . 13

2.3 Evaluation of the future labour market perspectives year by year ......................... 14

2.4 On the stability of the IFLM-labor market characteristics relationship . . . . . . . . . . . . . . 16

2.5 Evaluation of the future labour market perspectives by education 17

2.6 Qualitative evaluation for 2004 . . . . . . . . . . . 19

3 Methodology to derive the observed IFLM and the score 20

3.1 Introduction . . . . . . . . . . . . . . 20

3.2 Encompassing methodology . . . . . . . . . . . . . . 21

3.3 Results . . . . . . . . . . . . . . . . . . 22

4 Evaluation of forecast for each type of education 23

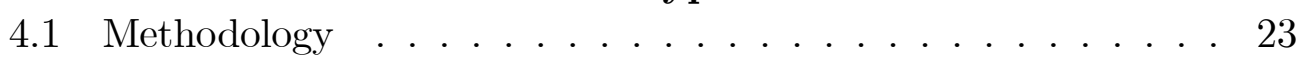

4.2 Results . . . . . . . . . . . . . . . . . 23 
5 Conclusion

24

6 References

25

Appendix

30 


\section{Introduction}

\subsection{Background}

The Research Centre for Education and the Labour Market generates every two years medium-term forecast of the labour market prospects of types of education and occupations. The first forecast were generated in 1989, after a pilot in 1987, under a contract from the Ministry of Education and Science. The project intended in first instance to cover the development of an information system of use especially for providing educational and vocational guidance to apprentices and students in secondary and higher education. Gained experience has shown that the information provided by ROA's forecast was also of primary interest for other labour market agents, namely policy makers and employers.

The labour market information provided by ROA's forecast are used various information products at the national level, for instance by the National Career Guidance Information Centre (LDC) and the Centre for Information on Higher Education for Consumer and Expert (CHOICE). The first forecast were used to supplement the labour market module I see!. This was a computerised information system, established by LDC, bringing together information from many sources which might be relevant for the choice of a career or course of study. Vocational guidance by teachers and others involved in assisting students to make these choices could call up this information via their personal computer and obtain, along with other information on study and vocational choices, an idea of the labour market consequences of the choices which were available. The LDC brought out another information system, 'Traject', which also makes use of labour market information provided by ROA. ROA's forecast have also been one of the foundations of the LDC's series of brochures for study and vocational guidance, and both the 'Keuzegids Hoger Onderwijs' and the 'Studiekeuze-Informatiedatabase' published by CHOICE. In addition to their own database, the Central for Work and Income (CWI) used the current data and the forecast of the information system to formulate policies on employment in general and vocational guidance for the unemployed in particular.

As part of this process, the first pilot research project was completed in 1987. This covered current labour market information and forecast for university education (De Grip, Heijke and Vos, 1987, De Grip et al., 1987a, 1987b and 1988). In 1989 the first forecast for the full width of the education 
system were compiled (De Grip et al., 1989 and De Grip, Heijke and Dekker, 1989), covering developments in the period up to and including 1992 for 79 occupational classes and 53 types of education. The forecast by occupational classes encompassed predictions of the expansion demand and replacement demand, which together comprise the 'job openings'. The forecast for the various types of education also included predictions of the expected supply, so that a confrontation of demand and supply could be made, on the basis of which a characterization could be given of the expected future labour market situation. The forecast were supplemented with current data and a number of indicators as regards the occupational classes and types of education which had been differentiated.

Since the first forecast in 1989, the ROA has generated eight waves of forecast, in 1990/91 and from 1993 on every two years. The latest forecast have been generated in 2005 concern the period running to 2010. The information system has undergone strong modifications and developments since 1989. For instance, the models used to generate forecast have been modified in order to adapt to more and more disaggregated educational and occupational classifications and provide more disaggregated information. The models have also benefited from the results of previous evaluation studies. The first forecast were evaluated in de Grip, Heijke and Berendsen (1991), and Borghans, van Eijs and de Grip (1994). The 1994 forecast were evaluated in Borghans, van Eijs and Smits (1996), the 1998 forecast in Smits and Diephuis (2001), the 2000 forecast in Cörvers, et al. (2004) and the 2002 forcast in Dupuy (2005). This report evaluates the 2006 forecast and the forecast quality of the Indicator of Future Labour Market (IFLM) position of educational types over time. This report also provides an overview of the methodology in used in the various parts of the model at the time the forecast were generated.

\subsection{Motivation for the evaluation}

Although the focus of attention, when compiling an evaluation of forecast, is mainly on the period in which the forecast was created and the period to which they related, an evaluation is also very important in relation to future forecasting activities.

For the users of forecast of the future labour market, differentiated by education and occupation, it is useful to have some information about the reliability of the forecast. Borghans (1993) has shown that publicly accessible predictions, as aids in choosing a course of study, have a positive influence on 
students' choices and therefore on the working of the labour market, provided that students have a reasonable idea of the usefulness of these forecast. Two things are important in this respect: the first is that the students have a clear concept of the rationale underlying the forecast. The total picture provided by a forecast should be broken down according to the factors from which it is composed, so that the basis on which particular developments are expected is clear. This makes it possible to compare the forecast with the students' own expectations of future labour market developments and/or various other sources of information. The second requirement is that students have an idea of the average accuracy of the predictions, because this in part determines the degree to which they have to take the forecast of the information system into account. It is therefore important to check which points the forecast is reasonably accurate on, and where the uncertainties lie. It is also important to know how the degree of uncertainty is expressed in the way in which the forecast are published.

A good evaluation of past forecast is also very important for those compiling forecast. When compiling forecast a choice must be made between the many possible ways of modelling the labour market. This choice is based on a certain understanding of the functioning of the market. If it was only the quality of the data which determined the quality of the forecast, the only lesson which could be derived from an evaluation would be a call for more or better data. But an evaluation of the forecast can also provide new understandings of the applicability of the methods used. This is especially so for forecast within an information system that is still in the development phase: a fundamental evaluation can also reveal the strong and weak points of the method.

Those who commission forecast are another group with an interest in the evaluation of the predictions. On one hand this evaluation can provide information as to the priorities which should guide the further development of the information system. On the other hand it is important for those commissioning forecast to know how useful the forecast are for their target group.

\subsection{Goal and structure of the forecast}

Any evaluation of forecast made within the framework of ROA's information system must rely on an assessment of the extent to which these forecast accomplish the purposes for which they were compiled. It is therefore im- 
portant to have a clear picture of the overall forecast structure and of the objectives of the forecast at the time they were made. This makes it possible to look at both the accuracy of the forecast and at how far the structure which was employed was suited to the goals which had been set.

\section{Purposes of the forecast}

The 1989 report formulated the primary and secondary goals of the Information System for Education and the Labour Market. "The ROA Information System for Education and the Labour Market has, at least for now, the primary goal of generating information which can be useful in choosing a course of study or an occupation. However this information system could in principle also be useful for capacity planning in the education system, and policies relating to the labour supply, the economic structure and technology, as well as the personnel policy of both the government and businesses." (De Grip, Heijke and Dekker, 1989, p. 1).

Because the second objective is presented here only as an option, and is moreover very general, this evaluation will be related specifically to the first of these objectives. This means that the forecast and the forecast structure will be examined throughout in terms of their usefulness for those choosing a course of study or an occupation.

The objective of generating information which can be useful in choosing a course of study and for vocational guidance has two implications for this evaluation. First of all, the structure of the information system needs to be suitable, so that the data which are generated can assist in the educational or vocational decisions of an individual student. i.e., the information must:

1. be relevant for the students;

2. be relevant at an individual level;

3. be presented in such a way that students can interpret it properly.

The first requirement, relevance for students, means that the forecast should relate to factors which can be important in making educational or vocational choices. That is, the forecast must provide understanding of the labour market situation which a student will encounter from the moment of entering the market after the completion of studies. This requirement thus determines the period to which the forecast must refer - the period in which 
students will have just left school - and the group in the labour market for which they must be relevant — the school-leavers.

The second requirement relates to significance at an individual level. Since the goal is to assist in educational and vocational decision-making, the forecast must be usable in making an individual choice regarding a particular type of education or occupation. For the student facing the choice of a course of study, it is relevant to know what situation he may face in the labour market at the end of his education. Some developments may be very relevant, in a general sense, for a description of the labour market, but only usable for an individual if they are translated to the individual level. For instance, the total growth in employment for a particular educational category is interesting for those making policy decisions, but for a student it is more important to know what his or her individual chance of getting a particular sort of work at the end of the course may be.

The third requirement for the structure of the forecast system, if it is to be usable for educational and vocational guidance, is that the information must be presented in an interpretable form. If they are to be usable for students, the forecast must for expressed in terms which are comprehensible for someone who is not entirely adept in labour market interpretations. The forecast results should, as far as possible, be expressed in generally understood concepts with a minimum of statistical or economic jargon. A translation is especially important for statistical judgments regarding the reliability of the forecast. Improvements in the ease of interpretation of the labour market data can however come in two ways: it may also be sensible to improve students' understanding of the functioning of the labour market so as to improve the comprehensibility of labour market information.

A second consequence of the objective of generating information which is useful for study and occupational choices is that the empirical evaluation will also be made from this standpoint. This means that the evaluation criterion which is used in determining the magnitude of forecasting errors must in the first place show what consequences these forecasting errors have had for individual occupational and vocational choices. The selection of a criterion for the evaluation is discussed in section 2.2 .

Structure of the forecast

Figure 1.1 gives a schematic overview of the structure of the forecasting method. On the demand side, the forecast of employment in economic sec- 
tors which are obtained from the Central Planning Bureau (CPB) provide an external source of information. These forecast are based on the so-called Athena model of CPB (see CPB 1993). At that time, these forecast covered 22 economic sectors. The predicted numbers employed in these economic sectors are then translated into the employment in 127 occupational classes. This predicted level of demand for occupations, when compared with the situation in 1985, yields the expected expansion demand for each occupational class. This is supplemented with a forecast of the expected replacement demand. Together, the expansion and replacement demand comprise the expected number of job openings. It is assumed that it is the number of job openings which is the relevant quantity for educational and vocational decisions. New entrants to the labour market cannot in practice simply crowd the people already working out of their jobs. On the basis of a breakdown of past flows into the labour market, a calculation is also made of how many of these job openings are available for school-leavers.

The expansion demand for each occupation is translated, by means of a distribution model, into the expansion demand per type of education. The replacement demand for the various types of education is calculated separately, because this cannot be derived from the replacement demand per occupation. Together, the replacement and expansion demand make up the total demand for new entrants with a particular educational background.

In addition to the forecast of demand, a forecast is made for each type of education of the expected supply of school-leavers entering the labour market between 1999 and 2004. These forecast are based on the forecast outflow of school-leavers from the educational system (Referentieramming) generated by the Ministry of Education, Culture and Science and supplemented with additional data on part-time education and courses outside the regular, government-supervised education system (i.e. 'non-regular' education). The total supply of new entrants together with the short-term unemployed at the beginning of the forecasting period determine the total supply. The assumption is that only short term unemployed workers at the beginning of the forecasting period compete with school-leavers. Based on the forecast of supply and demand, we calculate the 'indicator of the future labour market' (IFLM). This indicator gives an information about the tensions between demand and supply in the labour market in the period under consideration. Because the model which has been used takes no account of possible adjustments in the labour market in response to these tensions between demand and supply, this indicator of tension must not simply be regarded as the ex- 


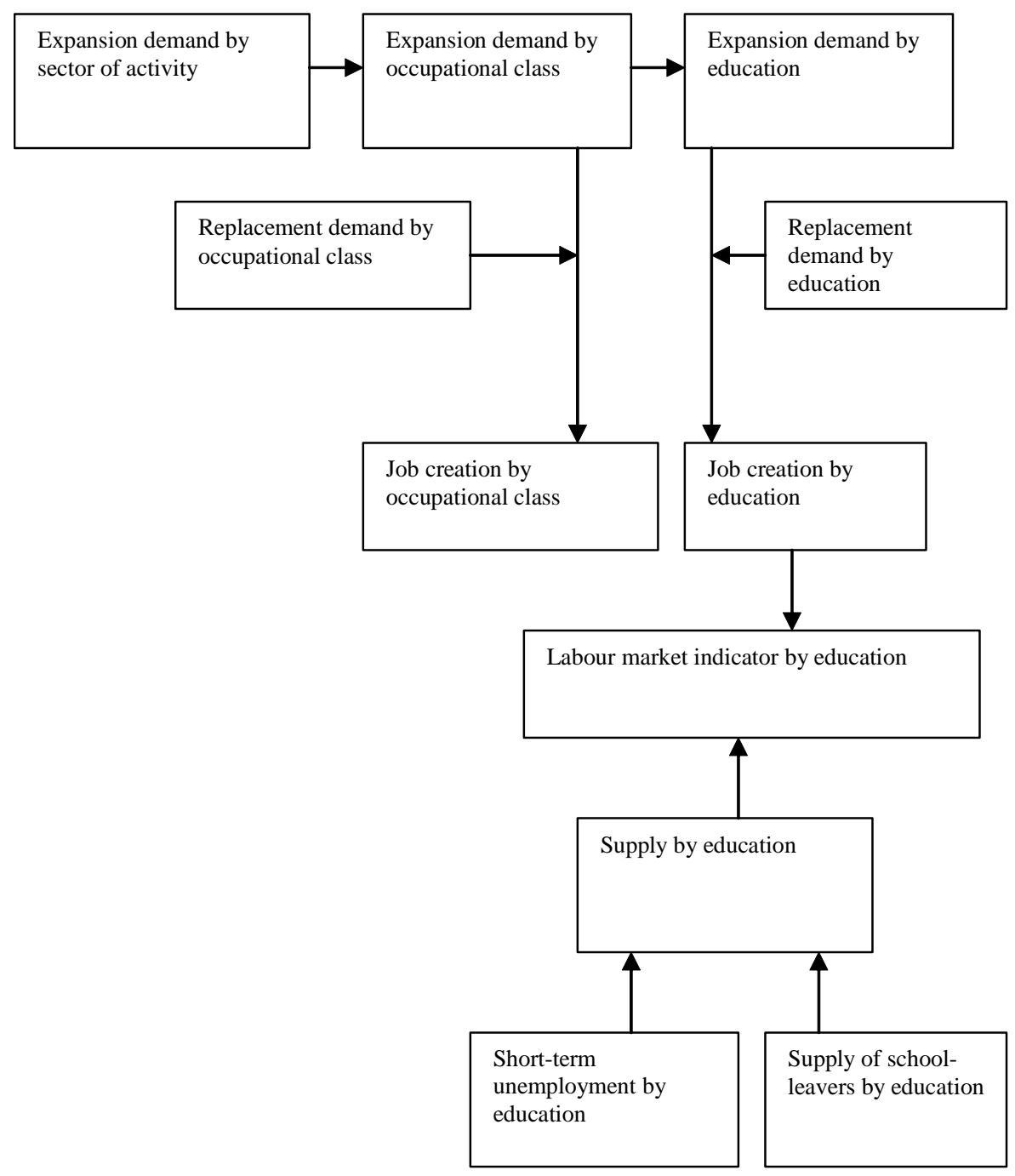

Figure 1: Structure of the forecasting model of the Information System on Education and the Labour Market 
pected over-supply or shortage. Naturally both the demand and supply sides of the labour market will to some extent adjust in response to these tensions, so that, for example, an over-supply of new entrants with a particular education will not necessarily be expressed in high unemployment, but could also lead to stagnating wages, an increased probability of having to find work outside of the intended field of employment, or other deteriorations in the labour market situation (see Wieling and Borghans (2001)).

In addition to these forecast of the number of job openings per occupational class, the information system also contains current data and indicators for each occupational class. The current data cover among other the number of workers in a particular occupational class, a breakdown into the component occupational groups, the age distribution of the workers, a breakdown by educational categories and types of education, economic sectors and sub-sectors, and the proportion of self-employed workers, plus the trends in these figures. The underlying idea is that such information can contribute to widening the horizons for those receiving educational and vocational guidance and in various ways give some understanding of a number of relevant characteristics of the labour market for a particular occupational class.

The indicators relate to the inflow of workers who are under 30 years old, the dispersion of the occupations among the various economic sectors and the sensitivity of employment to the state of the business cycle. The assimilation rate shows how many young people work in an occupation, as compared with other occupations. The dispersion over economic sectors and sensitivity to cyclical forces are both 'risk indicators'. The dispersion indicator shows how widely the employment for workers in this occupational class is spread over various economic sectors. If there is a wide dispersion, any unexpected change in a particular economic sector will have relatively little influence on the developments in that occupation. Wide dispersion would also indicate that, if demand in one of the economic sub-sectors should decline, there would probably be possibilities of work in other economic sectors. The sensitivity to cyclical forces shows the extent to which employment for the occupation rises and falls with the fluctuations in the business cycle. High cyclical sensitivity means, in the first place, an increased chance that the labour market prospects may deteriorate at some time later in a worker's career. It also indicates that there is a greater likelihood that the forecast will not be realized.

For educational types, the following data are presented (among other): employment level, percentage of female, and the percentage of workers overe- 
ducated for their job. Moreover, an indication is given of the dispersion of employment across occupations and economic sectors. Like the indicators for occupations, these dispersion indicators give an impression of the robustness of the forecast, but also show in a more general way the extent to which the choice of a particular type of education will leave students dependent on the labour market situation for a particular occupational class or a particular economic sector.

For educational and vocational guidance purposes, the quantitative data of the forecast, current data and indicators are all transformed into qualitative characterizations. On the basis of the values which have been established for the variables, a classification is made in each case on a five-point scale, on which the ranges are characterized as 'very low', 'low', 'average', 'high' or 'very high'. The intention of these qualitative characterizations is to render the quantitative figures of the forecast, indicators and current data more accessible for people who are not accustomed to dealing with such figures. In the first place they do not have to understand the measurement units in which the variables are measured. In the second place, this method gives an immediate relative characterization, so that it is not necessary to examine the dispersion of the variable. In the third place, the division into five intervals produces a characterization which gives a less exact impression than the figures themselves, avoiding the suggestion of accuracy to the last decimal point, and giving a certain bandwidth to the labour market forecast in particular.

\subsection{Structure of the report}

As can be seen from the diagram in Figure 1, at the heart of the forecasting model is the indicator of future labour market position (IFLM) of the various educational types. This indicator is also the forecast most often used by the tripartite, government, firms and students for it offers a synthetic measure of the future developments in the labour market. For this reason, we will concentrate our evaluation of the forecast exclusively on the IFLM.

Since the objective of this indicator is to provide information on the future position of graduates with the various educational backgrounds in the labour market over the next period of 5 years, evaluation of these indicators have usually been performed period per period assuming that the various educational groups react similarly to labour market discrepancies. This assumption was necessary since data were only available for one period, namely the pe- 
riod of forecasting horizon. However, since the ROA has been forecasting these indicators for several years now, it has become possible and certainly most relevant to analyze the extent to which this assumption is verified in the data. In this report, we will use as labour market discrepancies, indicators about unemployment, long term unemployment, the extent to which graduates with the various educational backgrounds work outside their own domain of specialization or under their educational level, the share of workers with part-time contracts, with permanent contracts and the average wage, to thoroughly evaluate the quality of the forecast of the IFLM for the years 2000, 2002, 2004 and 2006.

The remaining structure of this paper is as follows. In the next section, we will first evaluate year by year the score of the forecast and investigate the sensitivity of the IFLM to the various indicators of labour market discrepancies. Then, we will investigate the extent to which the relationship between the IFLM and the labour market discrepancies is stable over time making use of the time dimension in the data. Third, we will make use of the time dimension of our data to evaluate the extent to which all educational groups react the same way to discrepancies. Finally, the "realized" IFLM allows us to evaluate the qualitative aspect of the forecast of IFLM by educational type.

In section 3, we will discuss the methodology used to derive the "realized" IFLM. Since there is no single indicator of "realized" labour market position to which the IFLM could be compared in order to analyze its quality, which is the reason why ROA developed the IFLM indicator in the first place, we need to construct a "realized" indicator based on various labour market characteristics. The methodology used to construct this "realized" indicator is of importance since the score and the typering of the IFLM depend crucially on the "realized" indicator.

In section 4 , even though the short time dimension does not allow us to derive reliable quantitative results for each educational type, we report "descriptive" statistics that provide some information on the quality of the forecasts of the IFLM for each type. These statistics are, the sign of the forecasting errors for each year, i.e. 2002, 2004 and 2006 and the average and variance of the forecasting errors over time. Section 5 summarizes the results. 


\section{Confrontation of demand and supply}

\section{$2.1 \quad$ Introduction}

The labour market perspectives for educational types depend on both demand and supply factors. The gap between expected demand and supply flows is at the heart of the indicator of future labour market situation. This indicator reflects the expected labour market perspectives by educational type. The indicator has been subject to an important change since the forecast of 1994. Until 1994, the forecast accounted for the ex ante demand and supply by educational groups and not for the (passive) substitution demand that arises from shortages or surpluses in other educational groups. Since then, this substitution demand is accounted for. In this section, using the school-leaver inquiries RUBS, HBO-Monitor and WO-Monitor, we evaluate the extent to which the predicted perspectives correspond to the realized situation for the various educational types.

\subsection{Labour market indicator}

To get a good insight in the labour market perspective of an educational group of workers two things are important. First, the current labour market situation of each educational type. Discrepancies observed in the current labour market may take time to disappear. If the base year is characterized by surpluses some workers may become unemployed or to accept jobs outside their own field. Since workers who have not found an appropriate job possibly remain searching for a job in their own professional field for a while, they will compete with school-leavers who just entered the labour market. The question is of course how long does this situation last. At some point in time, unemployed workers or people working in jobs outside their field become perceived as less suitable by employers and are no longer considered for jobs in their own occupational field.

The impact of the current labour market situation has been partially taken into account in the IFLM. On the supply side, besides the supply of school-leavers forecast, the number of short term unemployed persons with the corresponding education at the beginning of the forecast period is taken into account. There it is therefore assumed that persons who are unemployed for more than one year are no serious competition for school-leavers. The same reasoning applies to shortages of labour. If employers cannot fill their 
vacancies with workers with the adequate skills, some of their vacancies will remain unfilled for a while. If vacancies are opened for a long period, employers will try to attract workers with another educational background or organize work differently. It can therefore be expected that the current discrepancies are especially important for the labour market perspective in the short run and less in the medium run. Therefore, the effect of a shortage at the beginning of the forecast period is not considered in the IFLM. This implies that vacancies are not considered in the demand side. On the demand side, the forecast for the expansion demand, the replacement demand and the substitution demand (only passive substitution is included) are considered.

The IFLM for each type of education is defined as follows:

$$
I F L M_{t: t+5}=\frac{L_{t}+S S_{t: t+5}+U_{t}}{L_{t}+J O_{t: t+5}+S D_{t: t+5}}
$$

where $L_{t}$ is employment at $t, S S_{t: t+5}$ is the forecast school-leavers supply in the period $t: t+5, U_{t}$ is the short term unemployment level, $J O_{t: t+5}$ is the forecast of job openings (positive expansion demand and replacement demand) and $S D_{t: t+5}$ the forecast of substitution demand for the period $t: t+5$.

\subsection{Evaluation of the future labour market perspec- tives year by year}

The IFLM gives an indication of the labour market perspectives of workers with the various educational backgrounds. As mentioned earlier, the current labour market situation is only partly considered in the determination of the IFLM, only short term unemployment is taken into consideration. The IFLM could be interpreted as the ratio of expected supply in 5 years from now to expected demand in 5 years from now. A bad labour market position means that the expected supply will exceed the expected demand. In the remaining of this section we will first evaluate the extent to which the IFLM is a good indicator of the changes in the labour market position of workers between $t$ and $t+5$. Discrepancies between demand for and supply of workers lead to a certain extent to unemployment or vacancies as noted earlier. If for a given educational type of workers, excess supply is observed, workers will have to adjust their job requirements. These workers will have to accept jobs below their level and with lower wages. In case of shortages, employers will have to 
improve their job offers in order to recruit the required workers. Moreover employers will probably have to recruit workers with other educational types and train them. To which extent discrepancies lead to unemployment or vacancies depends on the flexibility of the labour market and the substitution possibilities. To evaluate the forecast of the labour market perspective of workers we need to take into account this adjustment process that takes place in the labour market.

From the school-leaver surveys (RUBS, HBO monitor and WO monitor), the following labour market variables are available: unemployment rate, long term unemployment rate (percentage of school-leavers unemployed for more than 4 months), percentage school-leavers that find work outside their own domain, percentage that find work below their educational level, percentage with permanent contract, percentage with part time work and average (gross) monthly earnings (in 1,000 euros).

To determine how well the IFLM indicator did forecast the future labour market situation, we need to take all these indicators into account simultaneously. The equation we want to estimate is the following:

$$
I F L M_{j, t}=\beta_{t}^{0}+\sum_{k=1}^{K} \beta_{t}^{k} \times\left(y_{j, t}^{k}-\bar{y}_{j, t}^{k}\right)+e_{j, t}
$$

where $y_{j, t}^{k}$ is the labour market characteristic $k, k=1, \ldots, K$, for educational type $j$ at $t$ and, when educational codes are sorted by educational level, $\bar{y}_{j, t}^{k}$ is the mean of characteristic $k$ corresponding to the educational level to which $j$ belongs, i.e. we have: $\bar{y}_{j, t}^{k}=\frac{1}{\overline{l_{j}}-l_{j}} \sum_{i=\underline{l_{j}}}^{\overline{l_{j}}} y_{i, t}^{k}$ where $\underline{l_{j}}$ and $\overline{l_{j}}$ are respectively the first and the last educational code corresponding to the educational level to which $j$ belongs.

We are herewith not so much interested in the causality but rather in the extent to which these indicators simultaneously correlate with the IFLM. Using the estimates of equation 1, we derive the IFLM "realizations" as: $\widehat{I F L M}{ }_{j, t}=\beta_{t}^{0}+\sum_{k} \widehat{\beta}_{t}^{k} \times\left(y_{j, t}^{k}-\bar{y}_{j, t}^{k}\right)$. The estimation provides also a score for the labour market perspective forecast. Indeed, the score of the forecast is simply equal to $1-\bar{R}^{2}$ where $\bar{R}^{2}$ is the adjusted $R^{2}$ of the regression. The IFLM score for the periods ${ }^{1}$ 1995-2000, 1997-2002, 1999-2004 and 2001-2006

\footnotetext{
${ }^{1}$ The school-leaver survey for 2006 was not available at the time the analyses were run.
} 
is equal to $0.80,0.86,0.98$ and 0.96 respectively. It is interesting to note that the score has been increasing over time, indicating a worsening of the forecasting quality of IFLM. In section 3, we will explain why this pattern has emerged.

\subsection{On the stability of the IFLM-labor market charac- teristics relationship}

Equation 1 indicates that on average 13\% (the unweighted average of unadjusted $R^{2}$ in the 4 periods considered) of the variation in the IFLM across education coincides with variation in the levels of the various labour market characteristics $k$ across educational types. This therefore means that $87 \%$ of the variation in the IFLM across educational groups does not coincide with variation in these labour market characteristics. Indeed, the IFLM forecasts are derived from a structural model and depend on forecasts of expansion demand, replacement demand and supply by educational categories. The structural model takes into account complex structural changes in the labour market such as technical changes (in expansion demand). These changes are not directly accounted for by the labour market characteristics. Equation 1 is in fact a (partial) reduced form equation. This means that the beta coefficients in equation 1 cannot be used to identify the structural parameters of the model since they are themselves combinations of the structural parameters and/or variables of the model. This point is illustrated by the fact that those coefficients change over time as the structure of the model is affected by changes in the economy, i.e. technological change for instance affects expansion demand in complex ways that lead to substitution between skill groups of workers and might eventually lead some workers to work under their educational level or outside their field of specialization or even get unemployed.

To show the importance of these structural changes in the IFLM forecast, I propose to estimate equation 1 on the data pooled over the years. ${ }^{2}$

\footnotetext{
The analyses for 2006 are therefore based on the school-leaver survey for 2005.

${ }^{2}$ Since 2002, the educational classification has changed. Therefore, panel regressions are based on data for 2002, 2004 and 2006 only.
} 


$$
\begin{aligned}
\operatorname{IFLM}_{j, t}= & \beta^{0}+\sum_{k} \beta^{k} \times\left(y_{j, t}^{k}-\bar{y}_{j, t}^{k}\right) \\
& +\sum_{s}\left(\beta_{s}^{0} \times D_{s}+\sum_{k}\left(\beta_{s}^{k} \times\left(y_{j, t}^{k}-\bar{y}_{j, t}^{k}\right)\right) \times D_{s}\right)+e_{j, t}
\end{aligned}
$$

where $D_{t}$ is a dummy variable that takes for value 1 if $t=s$ and 0 otherwise.

Allowing for the coefficients to vary from year to year, allows us to perform a battery of t-tests on the $\beta_{s}$ coefficients as well as a simple F-test for the stability of the parameters, i.e. $H_{0}: \beta_{s}^{k}=0$ for all $s$ and $k=1, \ldots, K$. If equation 1 reflects a structural relationship, one should expect the $\beta$ coefficients to be constant over time, i.e. changes in IFLM between two periods are merely due to changes in the labour market characteristics $y^{k}$.

First, the null hypothesis of constant parameters over time can only be rejected at the $15 \%$ level as indicated by the $F-$ stat in table 2 . However, looking at the constancy of each parameter independently, the t-tests indicate significant variation over time for the constant term and the average wage. This analysis indicates that even though the labour market indicator forecast for year $t$ are significantly correlated with the observed labour market situation in year $t$ (for each year $t$ roughly $15 \%$ of the variation in IFLM across educational groups is explained by variation in labour market variables such as unemployment, wages etc. as indicated by the $R^{2}$ ), the forecast take into account not only changes in unemployment, wages etc. but also account for more complex structural changes captured by changes in the structural parameters of equation 1.

\subsection{Evaluation of the future labour market perspec- tives by education}

The analysis so far indicates that a small share of the IFLM is correlated with labour market characteristics across educational background. The relative non stability of the relationship between the IFLM and these characteristics also tend to indicate that IFLM takes into account complex changes that are only weakly approximated by weighting labour market characteristics. In the structural model that generates the IFLM, however, the educational groups are interrelated, but substitution across groups will depend on how different 
those groups are in terms of skills. Therefore, it might be reasonable to expect that workers with different educational backgrounds will react differently to similar labour market discrepancies. For some educational types, the labour market is more flexible and more substitution possibilities are available than for others. The true reduced form should therefore account for the fact that the link between IFLM and labour market characteristics may vary across educational groups. While such a model cannot be estimated using only one cross-section (too few observations within educational levels), pooling the data for several years and assuming that the parameters are constant over time (including time dummies), allows us to estimate coefficients that vary across educational levels.

The relationship we estimate here is the following: ${ }^{3}$

$$
\begin{aligned}
I F L M_{j, t}= & \beta^{0}+\sum_{s} \beta_{s}^{0} \times D_{s}+\sum_{k} \beta^{k} \times\left(y_{j, t}^{k}-\bar{y}_{j, t}^{k}\right) \\
& +\sum_{e}\left(\beta_{e}^{0} \times D_{e}+\sum_{k}\left(\beta_{e}^{k} \times\left(y_{j, t}^{k}-\bar{y}_{j, t}^{k}\right)\right) \times D_{e}\right)+e_{j, t}
\end{aligned}
$$

where $D_{e}$ is a dummy variable that takes for value 1 if education $j$ is at level $e, e=2,3,4$, and 0 otherwise.

As in the previous section, allowing for the coefficients to vary across educational levels, allows us to perform a battery of t-tests on the $\beta_{e}$ coefficients as well as a simple F-test for the stability of the parameters, i.e. $H_{0}: \beta_{e}^{k}=0$ for all $e$ and $k=1, \ldots, K$.

These results are reported in Table 3 . First, note that the educational dummies are all significant and decrease as the level of education increases, indicating that higher education is associated with systematic better future labour market perspectives. Second, most coefficients for the labour market characteristics are not significantly different from 0 and do not significantly differ across educational levels. These two results indicate that differences across educational levels in the IFLM are due to unobserved variables taken into account in the structural model but not capture by systematic variations in the labour market characteristics. Third, the IFLM for University studies is significantly related to the type of contract. A higher proportion of University graduates with permanent contracts tend to be positively related with

\footnotetext{
${ }^{3}$ Since 2002, the educational classification has changed. Therefore, panel regressions are based on data for 2002, 2004 and 2006 only.
} 
a better predicted future labour market position (lower IFLM). This means that the results presented in Table 3 are merely the result of a correlation between labour market characteristics and IFLM at the University level and not at lower educational levels.

\subsection{Qualitative evaluation for 2004}

The realizations of the IFLM derived from the estimation of equation 1 allow us to evaluate as in the other sections of this report the qualitative aspect of the forecast of IFLM by educational type. We assign to each forecast a qualitative characterization. The classification of characterizations is defined as follows: Very good: IFLM $\leq 0.85,0.85<I F L M \leq 1$ good, $1<$ IFLM $\leq 1.05$ average, $1.05<I F L M \leq 1.15$ moderate and IF $L M>1.15$ bad.

Table 1: Qualitative evaluation of labour market indicator by education.

\begin{tabular}{lrrrrrr}
\hline \hline & & Realization & & \\
Forecast & Very good & Good & Average & Moderate & Bad & Total \\
Very good & 0 & 8 & 1 & 0 & 0 & 9 \\
Good & 0 & 35 & 10 & 1 & 0 & 46 \\
Average & 0 & 12 & 3 & 0 & 0 & 15 \\
Moderate & 0 & 9 & 3 & 3 & 0 & 15 \\
Bad & 0 & 9 & 3 & 2 & 0 & 14 \\
Total & 0 & 73 & 20 & 6 & 0 & 99 \\
\hline
\end{tabular}

Table 3 indicates the extent to which the characterization of the forecast corresponds with the characterization of the realizations by educational type. Note that data where available for 99 categories only. It is also important to note that in equation 1 is estimated based on the forecast of IFLM and therefore assuming that the forecasting errors have expected mean equal to 0 . Since both the forecast and the realizations are measured with errors, the eventual noise in the type of the IFLM comes about not only because of forecasting errors but also because of discrepancies in the measurement errors between forecast and realizations.

The table indicates that the characterization assigned to each education has been relatively accurate. Indeed, 41 out of 99 educational types, that 
is $41 \%$, have been assigned the right characterization. In $1994,45 \%$ of the educational groups was assigned the correct characterization and in 1998 this percentage had increased to $52 \%$ and in 2002, $64 \%$. Moreover, 35 educational types have been assigned a characterization just one category away from the right category. This means that $77 \%$ of all educational types has the right characterization or almost.

\section{Methodology to derive the observed IFLM and the score}

\subsection{Introduction}

In section 2, we have shown that the score has been increasing over time. In this section, we argue that the methodology used to construct the "realized" IFLM is at the heart of this pattern. Indeed, evaluating the out of sample quality of IFLM forecast for a given variable requires to compare the forecast of this variable to the "realizations" of this variable. The problem when evaluating the IFLM indicators is that there is no single indicator of

"realized" labour market position to which the IFLM could be compared to analyze its quality. The non existence of such an indicator is the reason why ROA developed the IFLM indicator in the first place. To bypass this issue, we need to construct an indicator based on various labour market characteristics. As shown in the previous section, to evaluate the IFLM forecast, we usually construct a "realized" indicator by weighting out observed labour market characteristics referring to unemployment, wages, skill match etc.

There are two crucial assumptions made to identify the "realized" indicator. The first assumption is about which labour market characteristics to consider. For instance, should we use a single measure of wage distribution? If yes, which one would indicate the most accurately the labour market situation of graduates? The average wage? The proportion of workers earning less than a certain threshold? The wage dispersion? All these moments of the distribution of wages provide some information about the position of graduates in the labour market. Of course, in practice our choice will be limited by the number of observations (number of educational categories) and the richness of the available data in terms of available explanatory variables Since the first evaluation study in 1994, we have been using a set of 7 labour market characteristics to construct the "realized" indicator. These 
characteristics are: unemployment rate, long term unemployment rate (percentage of school-leavers unemployed for more than 4 months), percentage school-leavers that find work outside their own domain, percentage that find work below their educational level, percentage with permanent contract, percentage with part time work and average (gross) monthly earnings (in 1,000 euros).

Perhaps the most serious issue is the second assumption. The second assumption is about the value of the weights used to aggregate the various labour market characteristics into a single indicator. The choice of these weights is of course determinant for the evaluation of the quality of the forecast. The procedure chosen to determine the value of these weights has been to regress the IFLM forecast on the various labour market characteristics. The regression coefficients provide weights for our problem. Yet, even within this structure, there are very different ways to estimate the equation and thus derive the weights.

\subsection{Encompassing methodology}

Since education refers to both fields and levels and since the various labour market characteristics vary across both dimensions, a natural way to approach the problem is to allow each characteristic to contribute differently by levels and by fields. Roughly speaking, this means that the variation of IFLM across education can be decomposed into a between educational level effect and within educational level effect. This specification reads as follows:

$$
I F L M_{j, t}=\beta_{t}^{0}+\sum_{k=1}^{\max (L-1, K)} \gamma_{t}^{k} \times \bar{y}_{j, t}^{k}+\sum_{k=1}^{K} \beta_{t}^{k} \times\left(y_{j, t}^{k}-\bar{y}_{j, t}^{k}\right)+e_{j, t}
$$

where $L$ is the number of educational levels.

For instance, the specification chosen for the first evaluation of forecast in 1992 (See Borghans et al (1994)) and still in use in this study, was to de-mean the labour market characteristics and estimate equation 1, i.e. assuming $\gamma_{t}^{k}=0$ for all $k$ in equation 4 . In this specification, the model only explains within educational level variation in the IFLM indicators. The main argument motivating this specific choice was the rather limited number of 
observations available. Since the educational classification only distinguished between 40 categories at that time, it offered at most 32 degrees of freedom. However, this specification implicitly stipulates that the share of variation in IFLM due to variation in labour market characteristics across educational levels is 0. How stringent is this assumption? Obviously, when, at the various educational levels, the average IFLM are similar, the contribution of educational levels will be low, $\gamma_{t}^{k}$ will be close to 0 and equation 4 reduces to equation 1. Moreover, even if the average IFLM at the various educational levels are very different, the contribution of educational levels could be close to zero if the averages of the various labour market characteristics at the various educational levels are correspondingly large.

To evaluate the extent to which this assumption is suited for our data, I propose to estimate the general model in equation 4 . First, recognize that model in equation 4 is in fact a fixed effect model where each educational level has a specific shift parameter. Rearranging and changing the notation slightly the model reads as:

$$
I F L M_{j, t}=\beta_{t}^{0}+\sum_{l=1}^{L-1} \gamma_{t}^{k} \times D_{l, t}+\sum_{k=1}^{K} \beta_{t}^{k} \times y_{j, t}^{k}+e_{j, t}
$$

where $D_{l}$ is a dummy variable indicating the educational level $j$.

\subsection{Results}

Comparing the variation of IFLM explained via equation 1 and equation 5 , allows us to decompose the variance of IFLM (explained) into two parts: the within and between educational level variance. The results for each year are reported into table 4 . First, note that the score based on equation 5 varies between 0.75 in 2000 and 0.49 in 2004 and is lower in general than the "traditional" score as derived from equation 1 . This is due to the fact that we now account for between educational levels variance in IFLM in addition to the within educational levels variance.

The most striking result is that the share of between educational levels is rising since 2002 , from 32 to 88 percent. $^{4}$ A possible explanation for this pattern is the fact that actual skill upgrading has slowed down since the end of the 90s (see Dupuy 2006) while in the forecasting model used

\footnotetext{
${ }^{4}$ Results for 2000 are less comparable since we only have 73 observations.
} 
until the forecast to 2010, the speed of upgrading was kept constant due to data limitations (see ROA 2005). This means that expected demand for high skilled workers has been overestimated while expected demand for low skilled workers has been underestimated. As a consequence, the IFLM has been underestimated for high skilled workers and overestimated for low skilled workers. This biases resulted in an artificial increase in the IFLM variance between educational levels compared to the between educational level variance in the labour market characteristics.

\section{Evaluation of forecast for each type of ed- ucation}

\subsection{Methodology}

In this section, we evaluate the quality of the forecast for each educational type. Since we only have observations for three periods with the same educational classification, namely 2002, 2004 and 2006, we cannot derive reliable quantitative statistics. However, we can compute descriptive statistics to evaluate the quality of the forecasts for each educational type. The procedure is the following. We estimate model 1, estimation of equation 1 , for each year separately and derive the "realized" IFLM for each educational type. The forecasting errors are then defined by the difference between the IFLM and the "realized" IFLM, i.e. $\widehat{e}_{j, t}$. Hence, for each type of education $j$ we have three observations of the forecasting errors. To describe the content of these errors for each educational type we use the following statistics: the average forecasting errors, the variance of the forecasting errors and the sign of the errors. The last statistic actually counts the number of times, out of three observations, the forecasting error is greater than 0 . In addition, to illustrate the role played by the specification used to derive the "realized" IFLM in the forecasting errors for each type of education, we also derive these statistics for model 2, i.e. using the fixed effect method proposed in equation 5.

\subsection{Results}

The results are reported in Table 5. First, note that the mean errors, as derived from Model 1, are large and positive for lower education and large 
and negative for higher education. This is due to the fact that Model 1 does not account for between educational variance. Since model 2 account for the variance between educational level, this pattern is not observed using model 2 .

Second, using model 1, 9 educational types, PVE Food trades, PVE Agriculture, PVE Administration and Textile and leather trades, PVE Commerce, HVE Legal and fiscal, UE Construction and civil engineering, UE Civil engineering, UE Information science and UE Account, have a (absolute) mean error larger than 0.15. For these types of education, the IFLM seem to be systematically over or underestimated. In contrast, using model 2 , only 3 types of education, i.e. IVE Nursing and paramedical services, HVE Tourism and recreation and HVE Human resources have (absolute) mean errors larger than 0.15. This again highlights the importance of the specification used to derive the "realized" IFLM in analyzing the IFLM forecast.

\section{Conclusion}

The IFLM indicators are at the heart of the forecast by education and occupation. In this study we concentrated the evaluation of the forecast exclusively on the IFLM . Making use of the availability of forecast for several years, we were able to investigate the performance of the IFLM over time. In section 2, we have shown that, as derived from the traditional methodology to calculate the "realized" IFLM, the score was trending upwards which could indicate a worsening of the quality of the forecast.

In this paper we argued that this pattern in fact is artificial and does not indicate a worsening of the forecast but highlight the difficulty of measuring the quality of the IFLM forecast. Indeed, since there is no single indicator of "realized" labour market position to which the IFLM could be compared in order to analyze its quality, which is the reason why ROA developed the IFLM indicator in the first place, we need to construct a "realized" indicator based on various labour market characteristics. The "realized" indicator is actually the in-sample predicted IFLM from a regression of the IFLM on seven labour market characteristics.

First, we argued that this relationship is a reduced form equation not a structural one. The IFLM forecast are derived from a structural model and depend on forecast of expansion demand, replacement demand and supply by educational categories. The structural model takes into account complex 
structural changes in the labour market such as technical changes (in expansion demand). These changes are not directly accounted for by the labour market characteristics. This was illustrated by a battery of tests on the stability of the parameters of the relationship over time and across educational categories.

In section 4, we then showed that the regression specification employed to derive the "realized" was the actual source of the increase in the score. We have shown that a more general specification that accounts for systematic differences across educational levels in the IFLM provided more reliable scores that did not show any patterns over time. The most striking result was that the variance between educational levels is rising since 2002, from 32 to 88 percent. We argued that a possible explanation for this pattern is the fact that actual skill upgrading has slowed down since the end of the 90s (see Dupuy 2006) while, in the forecasting model used until the forecast to 2010, the speed of upgrading was kept constant due to data limitations (see ROA 2005). This means that expected demand for high skilled workers has been overestimated while expected demand for low skilled workers has been underestimated. As a consequence, the IFLM has been underestimated for high skilled workers and overestimated for low skilled workers. These biases have in turn resulted in an artificial increase in the IFLM variance between educational levels compared to the between educational level variance in the labour market characteristics.

Finally, we have derived some descriptive statistics of forecast quality for each educational type, namely, the average forecasting errors, the variance of the forecasting errors and the sign of the errors. The results showed that accounting for between educational levels variances in constructing the "realized" IFLM, the quality of the IFLM forecast improves noticeably for problematic educational types. Especially the forecast quality for PVE Food trades, PVE Agriculture, PVE Administration and Textile and leather trades, PVE Commerce, HVE Legal and fiscal, UE Construction and civil engineering, UE Civil engineering, UE Information science and UE Account is improved remarkably.

\section{References}

Beekman, Th.B.J., R.J.P. Dekker, A. de Grip, and J.A.M. Heijke (1989), An Explanation of the Educational Structure of Occupations, ROA-W-1989/3E, 
Maastricht (also published in Labour 5-3, 1992 pp. 151-163)

Borghans, L. (1991), De arbeidsmarkt en de invloed van voorspellingen, Economische Statistische Berichten, 76-3833, pp. 1113-1116.

Borghans, L. (1992), A Histo-Topographic Map of the Dutch University Studies, ROA-W-1992/5E, Maastricht.

Borghans, L. (1993), Educational Choice and Labour Market Information, thesis, University of Limburg, Maastricht.

Borghans, L., and J.A.M. Heijke (1996), Forecasting the Educational Structure of Occupations: A Manpower Requirements Approach with Substitution, Labour, vol. 10 (1), pp. 151-92.

Borghans, L., and J.A.M. Heijke (1994), Een random-coëfficiëntenmodel voor het voorspellen van de beroepenstructuur van bedrijfstakken, ROA-W1994/1.

Borghans, L., van Eijs, P. and de Grip, A. (1994), An evaluation of labour market forecasts by type of education and occupation for 1992, ROA-R1994/4E.

Borghans, L., A. de Grip, J. Delmee, J. van Loo and A. Matheeuwsen (1997), Methodiek arbeidsmarktprognoses en indicatoren 1997-2002, ROAW-1997/6.

Bosworth, D.L., G.J. Evans, and R.M. Lindley (1974), Mechanic Manpower Models, in: J.S. Wabe (ed), Problems in Manpower Forecasting, Westmead, pp. 61-84.

Clements, M.P. (1995), Rationality and the role of judgement in macroeconomic forecasting, Economic Journal, Vol. 105, pp. 410-420.

Clements, M.P., and D.H. Hendry (1993), Towards a Theory of Forecasting, unpublished paper.

CPB (1993), Athena; Een bedrijfstakkenmodel voor de Nederlandse economie, CPB, Den Haag.

Cörvers, F. B.J. Diephuis, A. Dupuy en P. van Eijs (2004), Evaluatie arbeidsmarktprognoses naar opleiding en beroep tot 2000, ROA-R-2004/8, Maastricht.

De Grip, A., L. Borghans and W. Smits (1998), Future Developments in the Job Level and Domain of High-skilled Workers, in: H. Heijke, L. Borghans (eds.), Towards a Transparent Labour Market for Educational Decisions, Ashgate, Aldershot/Brookfield USA/Singapore/Sydney, pp. 21-56.

De Grip, A., L.F.M. Groot, and J.A.M. Heijke (1987), Clustering Occupational Classes by Educational Structure, ROA-W-1987/2E, Maastricht (also 
published as: Defining Occupational Groupings by Educational Structure, Environment and Planning A, 1991, vol. 23 pp. 59-85)

De Grip, A., and J.A.M. Heijke (1991), Flexibiliteit versus produktiviteit, Onderzoek van Onderwijs, vol. 20-1, pp. 6-8.

De Grip, A., J.A.M. Heijke, and H. Berendsen (1991), Eerste evaluatie informatiesysteem onderwijs-arbeidsmarkt, ROA-R-1991/1, Maastricht.

De Grip, A., J.A.M. Heijke, J.W. van Dam, R.J.P. Dekker, and M.H. Wieling (1988), Aanvulling arbeidsmarktmodule I-See project (wetenschappelijk onderwijs), ROA-R-1988/2, Maastricht.

De Grip, A., J.A.M. Heijke, and R.J.P. Dekker (1989), The Labour Market by Education and Occupation to 1992, ROA-R-1989/8E, Maastricht.

De Grip, A., J.A.M. Heijke, R.J.P. Dekker, Th.B.J. Beekman, and H.M.M. Peeters (1989), De arbeidsmarktperspectieven van beroepsklassen en opleidingstypen in 1992: rapportage I-See!, ROA-R-1989/7, Maastricht.

De Grip, A., J.A.M. Heijke, R.J.P. Dekker, and L.F.M. Groot (1987a), Labour Market Prospects for Occupations and Academic Studies in 1992, ROA-W-1987/1E, Maastricht.

De Grip, A., J.A.M. Heijke, R.J.P. Dekker, L.F.M. Groot, and L.A. Vos (1987b), De arbeidsmarktperspectieven van studierichtingen in het wetenschappelijk onderwijs, Arbeidsmarktmodule I-See project, ROA-R-1987/3, Maastricht.

De Grip, A., J.A.M. Heijke, and L.A. Vos (1987), Inventariserend onderzoek arbeidsmarktmodule I-See project, ROA-R-1987/1, Maastricht.

De Grip, A., and E.J.T.A. Willems (1992), De vervangingsvraag naar beroepsklasse tot 2000, OSA-W 96, Den Haag.

Dekker, R.J.P., and A. de Grip, Vergelijking tussen de CBS- en de ROAberoepenclassificatie, ROA-W-1992/3, Maastricht.

Dekker, R.J.P., A. de Grip, Th.B.J. Beekman, P.J.E. van de Loo, M.H. Wieling, and E.J.T.A. Willems (1990), Rapportage I-See! 1990, ROA-R1990/6, Maastricht.

Dekker, R.J.P., A. de Grip, H. Berendsen, M.H. Wieling, and E.J.T.A. Willems (1992), Methodiek en structuur arbeidsmarktmodule I-See! 1991, ROA-W-1992/1, Maastricht.

Dekker, R.J.P., A. de Grip, L. Borghans, A.G.M. Matheeuwsen, M.H. Wieling, and E.J.T.A. Willems (1993), Methodiek van het informatiesysteem onderwijs-arbeidsmarkt 1993, ROA-W-1993/3, Maastricht.

Dupuy (2005), An evaluation of the labour market forecasts by type of education and occupation for 2002, ROA-W-2005/1E. 
Dupuy (2006), A., Measuring skill-upgrading in the Dutch labor market, ROA-W-2006/3E.

Evans, G.J., and R.M. Lindley (1973), The use of RAS and Related Models in Manpower Forecasting, Economics of Planning, 13-12, pp. 5373.

Granger, C.W.J., and Newbold (1986), Forecasting Economic Time Series, Academic Press Inc., Orlando.

Heijke, H., A. Matheeuwsen and E. Willems (2003), Clustering Educational Categories in a Heterogeneous Labour Market, Education Economics, Vol. 11, pp. 89-108.

Matheeuwsen, A. and A. de Grip (1997), De doorstroom van het reguliere naar het niet-reguliere onderwijs, ROA-W-1997/4.

Ministerie van Onderwijs, Cultuur en Wetenschappen (1997), Referentieraming 1997, Zoetermeer.

ROA (1997), De arbeidsmarkt naar opleiding en beroep tot 2002, ROAR-1997/7, Maastricht.

ROA (2005), De arbeidsmarkt naar opleiding en beroep tot 2010, ROAR-2005/9, Maastricht

Smits, W. and B. Diephuis (2001), Evaluatie arbeidsmarktprognoses naar opleiding en beroep tot 1998, ROA-R-2001/2, Maastricht.

Theil, H. (1958), Economic forecasts and policy. Amsterdam.

Van der Velden, R., and L. Borghans (1993), Competition on the Labour Market. An Analysis of the Position of Types of Training', ROA-RM-1993/5E, Maastricht.

Van Eijs, P. (1993), The Manpower Requirements Approach, Background and Methodology, ROA-RM-1993/3E, Maastricht.

Van Eijs, P., and L. Borghans (1997), The use of RAS in manpower forecasting: a microeconomic approach, in: Economic Modelling, Elsevier Science, B.V., 1996, pp. 257-287.

Vlasblom, J.D., B.J. Diephuis, S. Dijksman, P. Marey (2000), Ontwikkelingen op de arbeidsmarkt in 2001, ROA-R-2000/10, Maastricht.

Wieling, M.H., A. de Grip, and E.J.T.A. Willems (1990), Een systematische kwalitatieve typering van arbeidsmarktinformatie, ROA-W-1990/8, Maastricht also published as 'Forecasting Replacement Demand by Occupation and Education'. International Journal of Forecasting 9, 1993, pp. 173-185).

Wieling, M. and L. Borghans (2001), Discrepancies between Supply and Demand and Adjustment Processes in the Labour Market, Labour, Vol. 15 
(1), pp.33-56.

Wilson, R. (1994), Modelling and Forecasting the Structure of Employment in the United Kingdom, in: H. Heijke (ed), Forecasting the Labour Market by Occupation and Education, Boston, pp. 9-35.

Willems, E.J.T.A., A. de Grip (1993), Forecasting Replacement Demand by Occupation and Education, in: International Journal of Forecasting, vol. 9, pp. $173-185$.

Willems, E.J.T.A. (1996), Manpower Forecasting and Modelling Replacement Demand: an Overview, ROA-W-1996/4E. 
Appendix 


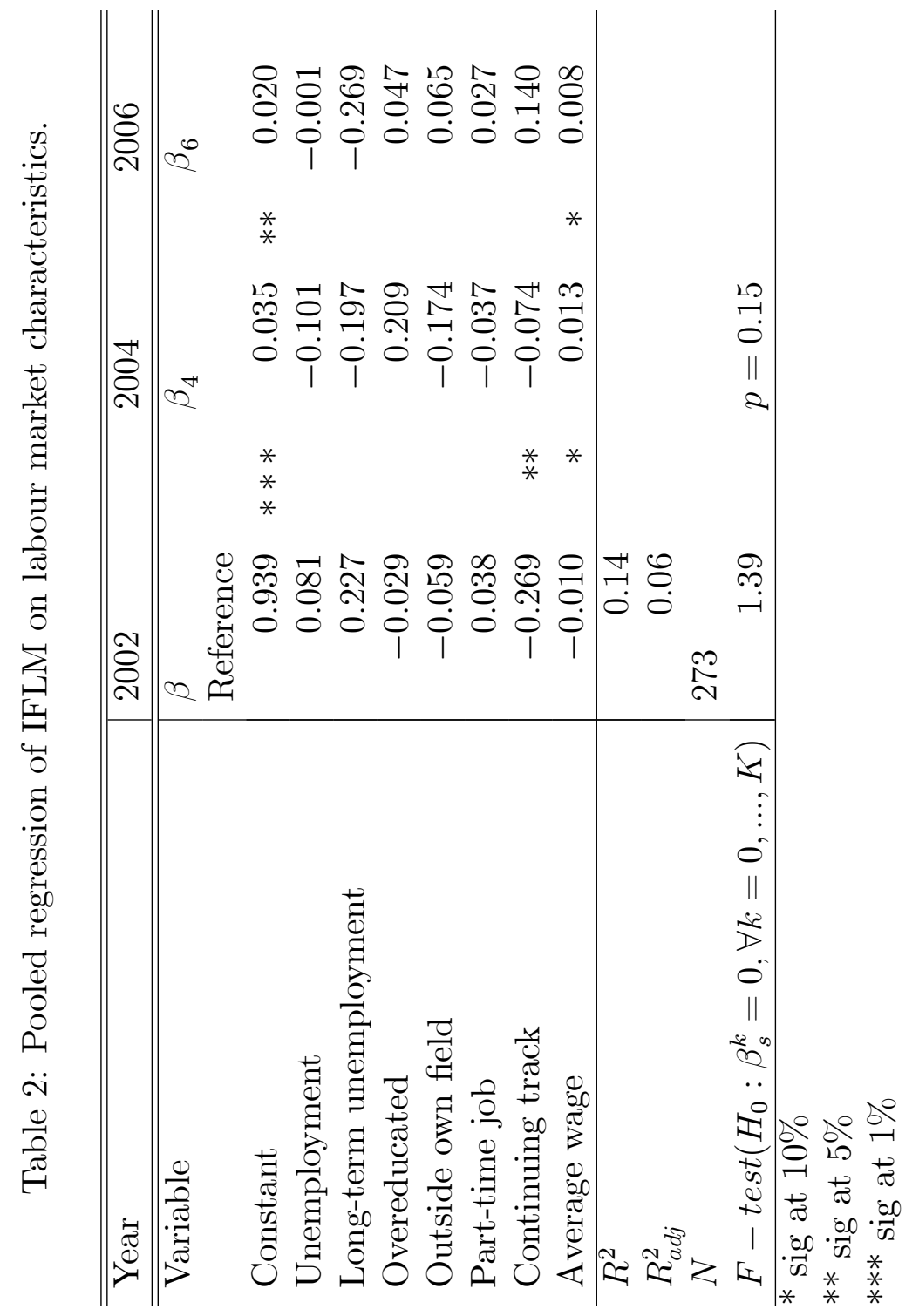




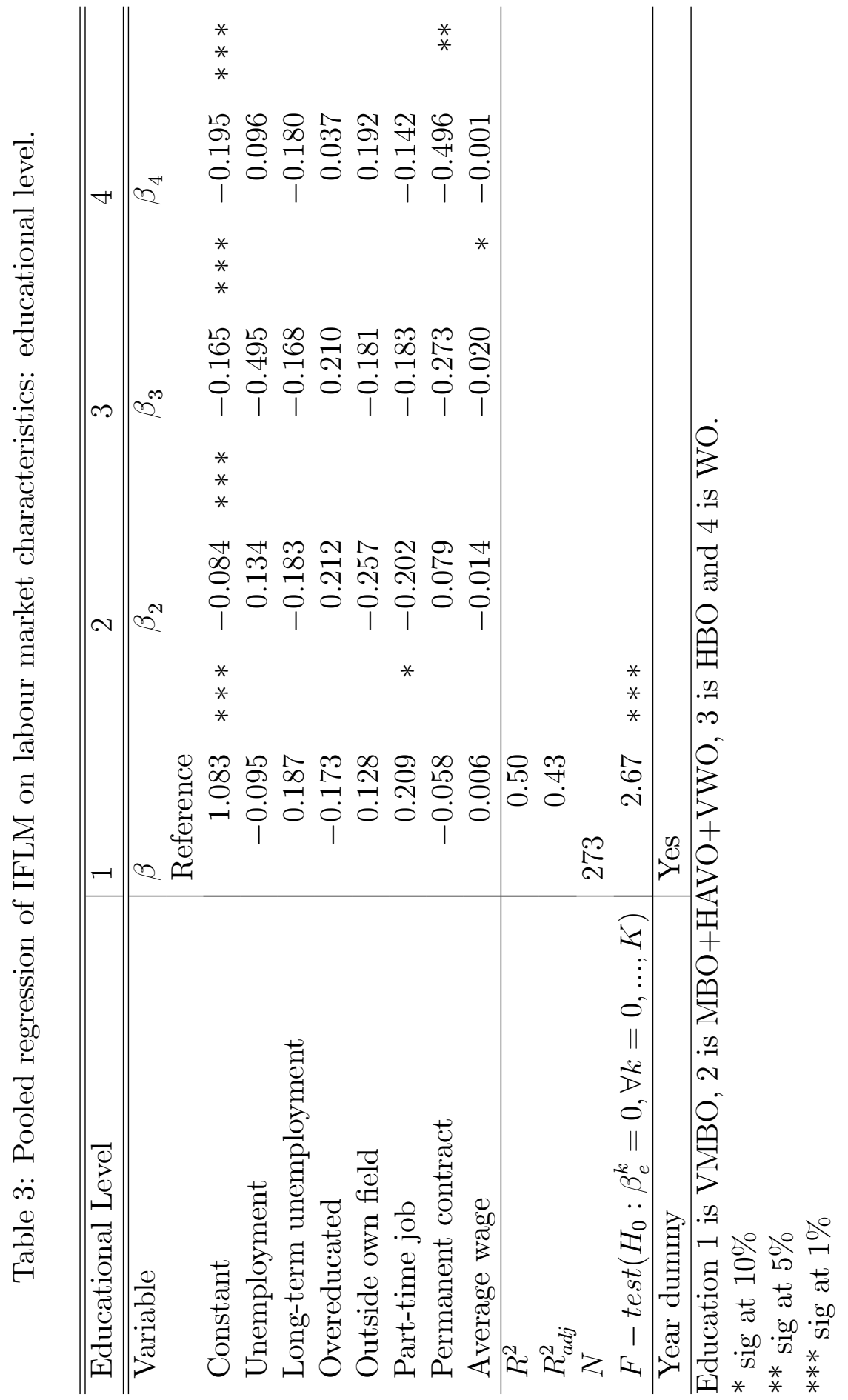




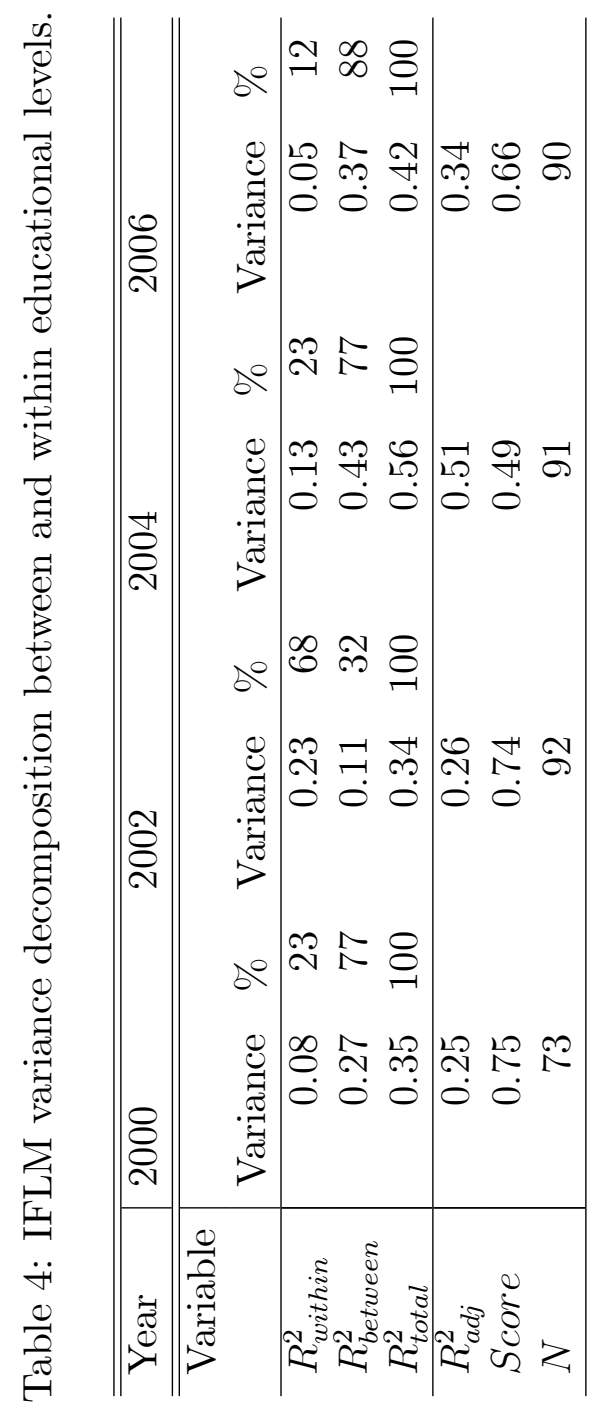




\begin{tabular}{|c|c|c|c|c|c|c|}
\hline Education & $\begin{array}{r}\text { Mean errors } \\
\text { Model } 1\end{array}$ & $\begin{array}{r}\text { Variance errors } \\
\text { Model } 1\end{array}$ & $\begin{array}{r}\text { Mean errors } \\
\text { Model } 2\end{array}$ & $\begin{array}{r}\text { Variance errors } \\
\text { Model } 2\end{array}$ & $\begin{array}{r}\text { Number of } \\
\text { positive errors } \\
\text { Model } 1\end{array}$ & $\begin{array}{r}\text { Number of } \\
\text { positive errors } \\
\text { Model } 2\end{array}$ \\
\hline Lower General Secondary Education & 0,07 & 0,0007 & $-0,05$ & 0,0001 & 3 & 0 \\
\hline PVE Agriculture & 0,18 & 0,0166 & 0,06 & 0,0105 & 3 & 2 \\
\hline PVE Construction trades & 0,16 & 0,0030 & 0,04 & 0,0004 & 3 & 3 \\
\hline PVE Mechanical trades & 0,05 & 0,0006 & $-0,06$ & 0,0040 & 3 & 1 \\
\hline PVE Automobile trades & 0,13 & 0,0017 & 0,01 & 0,0002 & 3 & 2 \\
\hline PVE Electrical trades & 0,06 & 0,0046 & $-0,06$ & 0,0011 & 2 & 0 \\
\hline PVE Food trades & 0,18 & 0,0014 & 0,05 & 0,0031 & 3 & 2 \\
\hline PVE Administration and Textile and leather trades & 0,19 & 0,0173 & 0,07 & 0,0086 & 3 & 2 \\
\hline PVE Commerce & 0,19 & 0,0087 & 0,08 & 0,0095 & 3 & 2 \\
\hline PVE Community care, hotel and catering & 0,11 & 0,0005 & $-0,01$ & 0,0017 & 3 & 1 \\
\hline PVE Security & 0,04 & 0,0072 & $-0,08$ & 0,0133 & 2 & 1 \\
\hline Higher General Secondary Education & 0,07 & 0,0018 & 0,02 & 0,0011 & 3 & 2 \\
\hline IVE Agriculture & $-0,02$ & 0,0023 & $-0,06$ & 0,0026 & 1 & 0 \\
\hline IVE natural environment & 0,08 & 0,0012 & 0,04 & 0,0005 & 3 & 3 \\
\hline IVE Technical Laboratory & 0,06 & 0,0011 & 0,01 & 0,0008 & 3 & 1 \\
\hline IVE Construction technology & 0,01 & 0,0017 & $-0,03$ & 0,0007 & 2 & 1 \\
\hline IVE Civil engineering & 0,14 & 0,0144 & 0,10 & 0,0099 & 2 & 2 \\
\hline IVE Instalation & 0,07 & 0,0045 & 0,03 & 0,0038 & 3 & 2 \\
\hline IVE Mechanical engineering & 0,06 & 0,0014 & 0,03 & 0,0006 & 3 & 2 \\
\hline IVE Precision engineering & 0,00 & 0,0035 & $-0,04$ & 0,0027 & 1 & 1 \\
\hline IVE Automobile technology & 0,04 & 0,0016 & 0,00 & 0,0008 & 2 & 1 \\
\hline IVE Operational technology & 0,08 & 0,0132 & 0,04 & 0,0118 & 2 & 1 \\
\hline IVE Electrical technology & 0,04 & 0,0018 & 0,00 & 0,0007 & 2 & 1 \\
\hline IVE Printing technology & 0,11 & 0,0018 & 0,06 & 0,0036 & 3 & 2 \\
\hline IVE Process technologies & 0,02 & 0,0029 & $-0,02$ & 0,0022 & 2 & 1 \\
\hline IVE Bakery and catering technology & 0,10 & 0,0033 & 0,07 & 0,0035 & 3 & 2 \\
\hline IVE Food technology & 0,13 & 0,0015 & 0,08 & 0,0009 & 3 & 3 \\
\hline IVE Transport and harbour & $-0,02$ & 0,0018 & $-0,06$ & 0,0031 & 1 & 1 \\
\hline IVE Doctors, dentists and veterinaries assistant & 0,14 & 0,0021 & 0,10 & 0,0024 & 3 & 3 \\
\hline IVE Nursing and paramedical services & $-0,11$ & 0,0015 & $-0,15$ & 0,0019 & 0 & 0 \\
\hline IVE Social and cultural & 0,07 & 0,0005 & 0,03 & 0,0003 & 3 & 3 \\
\hline IVE Community care & 0,10 & 0,0017 & 0,06 & 0,0024 & 3 & 2 \\
\hline
\end{tabular}




\begin{tabular}{|c|c|c|c|c|c|c|}
\hline Education & $\begin{array}{r}\text { Mean errors } \\
\text { Model } 1\end{array}$ & $\begin{array}{r}\text { Variance errors } \\
\text { Model } 1\end{array}$ & $\begin{array}{r}\text { Mean errors } \\
\text { Model } 2\end{array}$ & $\begin{array}{r}\text { Variance errors } \\
\text { Model } 2\end{array}$ & $\begin{array}{r}\text { Number of } \\
\text { positive errors } \\
\text { Model } 1\end{array}$ & $\begin{array}{r}\text { Number of } \\
\text { positive errors } \\
\text { Model } 2\end{array}$ \\
\hline IVE hairdressing, Manicures & 0,00 & 0,0075 & $-0,04$ & 0,0052 & 2 & 1 \\
\hline IVE Hotel, catering & $-0,05$ & 0,0048 & $-0,10$ & 0,0035 & 1 & 0 \\
\hline IVE Therapeutics and Orthopaedics & 0,10 & 0,0054 & 0,06 & 0,0065 & 3 & 2 \\
\hline IVE Administration & $-0,04$ & 0,0004 & $-0,09$ & 0,0007 & 0 & 0 \\
\hline IVE Retail & 0,06 & 0,0002 & 0,02 & 0,0008 & 3 & 2 \\
\hline IVE Secretariat & $-0,08$ & 0,0002 & $-0,13$ & 0,0002 & 0 & 0 \\
\hline IVE Tourism and recreation & 0,11 & 0,0231 & 0,06 & 0,0285 & 2 & 1 \\
\hline IVE Police, fire and defense & $-0,08$ & 0,0016 & $-0,11$ & 0,0006 & 0 & 0 \\
\hline HVE Teacher training primary education & $-0,08$ & 0,0024 & $-0,03$ & 0,0012 & 0 & 1 \\
\hline HVE Teacher training languages & $-0,07$ & 0,0002 & $-0,03$ & 0,0007 & 0 & 1 \\
\hline HVE Teacher training technology and natural sciences & $-0,04$ & 0,0002 & 0,00 & 0,0003 & 0 & 2 \\
\hline HVE Teacher training economics and Sociology & $-0,14$ & 0,0031 & $-0,10$ & 0,0040 & 0 & 0 \\
\hline HVE Teacher training physical education & 0,00 & 0,0038 & 0,05 & 0,0018 & 2 & 2 \\
\hline HVE Teacher training health & $-0,11$ & 0,0017 & $-0,07$ & 0,0028 & 0 & 0 \\
\hline HVE Teacher training expression & $-0,07$ & 0,0028 & $-0,03$ & 0,0029 & 0 & 2 \\
\hline HVE Teacher training interpreter and translator & $-0,06$ & 0,0002 & $-0,02$ & 0,0008 & 0 & 1 \\
\hline HVE Agriculture and environmental science & $-0,08$ & 0,0011 & $-0,04$ & 0,0023 & 0 & 1 \\
\hline HVE Environment sciences & 0,07 & 0,0010 & 0,11 & 0,0003 & 3 & 3 \\
\hline HVE Technical laboratory & $-0,08$ & 0,0035 & $-0,03$ & 0,0015 & 0 & 1 \\
\hline HVE Construction & $-0,05$ & 0,0005 & 0,00 & 0,0016 & 0 & 1 \\
\hline HVE civil engineering & $-0,05$ & 0,0020 & 0,00 & 0,0014 & 1 & 1 \\
\hline HVE Mechanical engineering & $-0,03$ & 0,0003 & 0,01 & 0,0011 & 0 & 1 \\
\hline HVE Electronic & $-0,04$ & 0,0017 & 0,00 & 0,0014 & 1 & 2 \\
\hline HVE information technology & $-0,10$ & 0,0022 & $-0,06$ & 0,0010 & 0 & 0 \\
\hline HVE chemical technology & $-0,07$ & 0,0032 & $-0,03$ & 0,0040 & 1 & 1 \\
\hline HVE Transport and harbour & $-0,12$ & 0,0003 & $-0,07$ & 0,0002 & 0 & 0 \\
\hline HVE Nursing and paramedical services & $-0,06$ & 0,0007 & 0,00 & 0,0005 & 0 & 2 \\
\hline HVE (Physio)therapy & $-0,09$ & 0,0030 & $-0,04$ & 0,0016 & 0 & 1 \\
\hline HVE Nutritionist & $-0,02$ & 0,0022 & 0,03 & 0,0007 & 2 & 2 \\
\hline HVE Economics & $-0,02$ & 0,0049 & 0,03 & 0,0026 & 1 & 2 \\
\hline HVE Commerce & 0,03 & 0,0019 & 0,07 & 0,0016 & 2 & 3 \\
\hline
\end{tabular}




\begin{tabular}{|c|c|c|c|c|c|c|}
\hline Education & $\begin{array}{r}\text { Mean errors } \\
\text { Model } 1\end{array}$ & $\begin{array}{r}\text { Variance errors } \\
\text { Model } 1\end{array}$ & $\begin{array}{r}\text { Mean errors } \\
\text { Model } 2\end{array}$ & $\begin{array}{r}\text { Variance errors } \\
\text { Model } 2\end{array}$ & $\begin{array}{r}\text { Number of } \\
\text { positive errors } \\
\text { Model } 1\end{array}$ & $\begin{array}{r}\text { Number of } \\
\text { positive errors } \\
\text { Model } 2\end{array}$ \\
\hline HVE Tourism and recreation & 0,13 & 0,0240 & 0,17 & 0,0227 & 3 & 3 \\
\hline HVE Legal and fiscal & $-0,16$ & 0,0062 & $-0,13$ & 0,0088 & 0 & 0 \\
\hline HVE Secretariat & $-0,09$ & 0,0012 & $-0,05$ & 0,0015 & 0 & 0 \\
\hline HVE Business administration & 0,07 & 0,0005 & 0,10 & 0,0017 & 3 & 3 \\
\hline HVE Communication and journalism & 0,01 & 0,0048 & 0,04 & 0,0039 & 1 & 2 \\
\hline HVE Social and cultural & $-0,04$ & 0,0016 & 0,01 & 0,0010 & 1 & 2 \\
\hline HVE Human resources & 0,13 & 0,0099 & 0,17 & 0,0068 & 3 & 3 \\
\hline HVE Fine Arts & $-0,04$ & 0,0002 & 0,00 & 0,0009 & 0 & 2 \\
\hline UE Literature & $-0,05$ & 0,0004 & 0,02 & 0,0000 & 0 & 3 \\
\hline UE Theology & $-0,12$ & 0,0029 & $-0,05$ & 0,0018 & 0 & 1 \\
\hline UE Agriculture and environmental science & 0,01 & 0,0001 & 0,08 & 0,0009 & 2 & 3 \\
\hline UE Mathematics and natural sciences & $-0,05$ & 0,0004 & 0,02 & 0,0003 & 0 & 2 \\
\hline UE Construction and civil engineering & $-0,16$ & 0,0006 & $-0,08$ & 0,0004 & 0 & 0 \\
\hline UE Civil engineering & $-0,15$ & 0,0037 & $-0,08$ & 0,0027 & 0 & 0 \\
\hline UE Mechanical engineering & $-0,02$ & 0,0045 & 0,05 & 0,0018 & 2 & 2 \\
\hline UE Electrical engineering and inform. tech. & $-0,10$ & 0,0013 & $-0,03$ & 0,0005 & 0 & 0 \\
\hline UE Information science & $-0,19$ & 0,0044 & $-0,11$ & 0,0025 & 0 & 0 \\
\hline UE Veterinary and medical sci. & $-0,02$ & 0,0007 & 0,04 & 0,0023 & 1 & 3 \\
\hline UE Pharmacy & 0,01 & 0,0018 & 0,08 & 0,0045 & 1 & 3 \\
\hline UE Econom-ics (etry) & $-0,09$ & 0,0034 & $-0,02$ & 0,0019 & 0 & 1 \\
\hline UE Business administration & $-0,10$ & 0,0002 & $-0,03$ & 0,0002 & 0 & 0 \\
\hline UE Accounting & $-0,18$ & 0,0026 & $-0,11$ & 0,0007 & 0 & 0 \\
\hline UE Law \& Management & $-0,01$ & 0,0006 & 0,05 & 0,0000 & 1 & 3 \\
\hline UE Social sciences & $-0,08$ & 0,0023 & $-0,01$ & 0,0006 & 0 & 2 \\
\hline UE Fine Arts & 0,07 & 0,0033 & 0,14 & 0,0009 & 2 & 3 \\
\hline Total & 0,00 & 0,0034 & 0,00 & 0,0030 & 1,39 & 1,44 \\
\hline
\end{tabular}

